\title{
Свойства ВКР-преобразования частично когерентных ультракоротких импульсов
}

\author{
А.В. Иваненко", А.Ю. Кохановский, М.Д. Гервазиев, С.В. Смирнов, С.М. Кобцев \\ Новосибирский государственный университет \\ ${ }^{*}$ E-mail: ivanenko.aleksey@gmail.com
}

DOI:10.31868/RFL2018.78-79

При синхронизации мод излучения волоконных лазеров могут генерироваться импульсы различных типов [1], в числе которых частично когерентные импульсы, отличающиеся относительно сложной структурой электромагнитного поля (т.н. “двухмасштабные импульсы”) [2]. Интерес к этим импульсам обусловлен тем, что они могут нести рекордно высокую энергию и обеспечивать рекордную среднюю мощность излучения непосредственно в волоконных задающих генераторах [3-5] без использования дополнительных каскадов усиления. Важной особенностью этих импульсов является то, что они обеспечивают относительно высокую эффективность нелинейно-оптических преобразований $[6,7]$. В данной работе впервые представлены результаты исследования свойств ВКР-преобразования двухмасштабных импульсов в фосфорно-силикатном волокне.

Схема экспериментальной установки приведена на рис. 1.

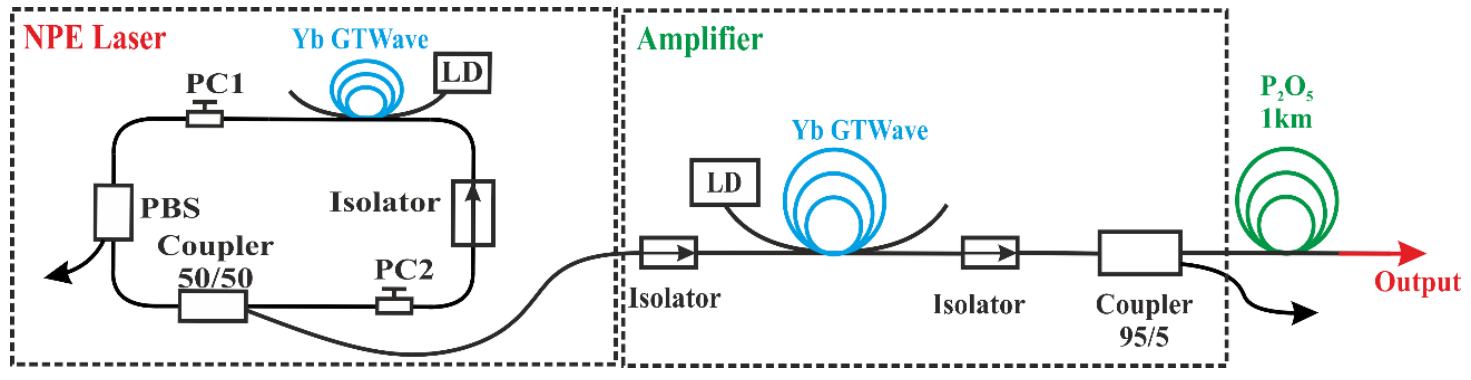

Рис. 1. Схема лазерной установки: NPE Laser - лазер с синхронизацией мод за счёт эффекта нелинейной эволюции поляризации, Amplifier - волоконный усилитель, PBS - волоконный поляризационный делитель, Isolator - изолятор, Coupler - ответвитель, PC1, PC2 - контроллеры поляризации.

Двухмасштабные импульсы генерировались иттербиевым волоконным задающим генератором с синхронизацией мод излучения за счёт эффекта нелинейной эволюции поляризации излучения. Средняя мощность выходного излучения составляла 50 мВт, длительность импульсов - 16 пс. Настройка контроллеров поляризации PC1 и PC2 позволяла подбирать режимы синхронизации мод, отличающиеся степенью когерентности импульсов, при этом длительность импульсов и средняя мощность выходного излучения практически не изменялись. Выходное излучение задающего генератора подавалось на вход волоконного усилителя на основе иттербиевого GTWave волокна, на выходе которого средняя мощность излучения составляла 1 Вт. Далее излучение заводилось в кварцевое волокно, легированное фосфором, длиной 1 км.

На рис. 2 приведены автокорреляционные функции двухмасштабных импульсов с различной степенью когерентности и спектры излучения на выходе $\mathrm{P}_{2} \mathrm{O}_{5}$-волокна в зависимости от степени когерентности импульсов. Видно, что степень когерентности двухмасштабных импульсов существенно влияет не только на длину волны и интенсивность стоксовой волны, но и на ширину и форму её спектра излучения. Импульсы с наименьшей степенью когерентности 
отличаются более интенсивными внутриимпульсными флуктуациями поля, что обуславливает более значительное нелинейное преобразование этих импульсов.
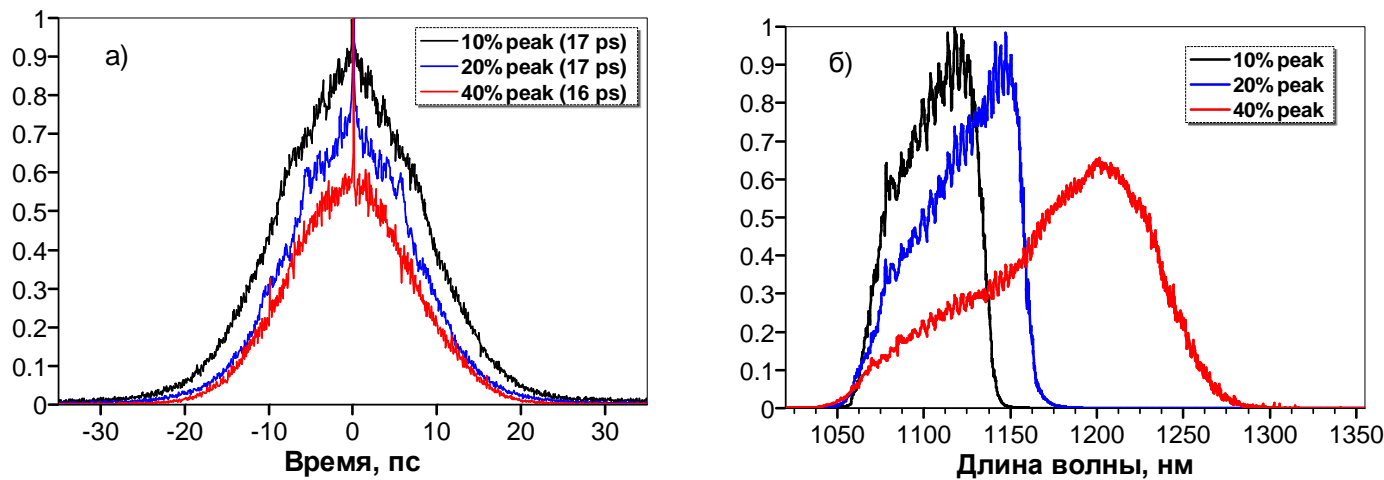

Рис. 2. Автокорреляционные функции импульсов с разной высотой пика (а) и оптические спектры на выходе Р2О5 волокна в зависимости от входных импульсов (б).

На рис. 3 приведена зависимость ширина спектра излучения стоксовой волны от относительной амплитуды узкого пика автокорреляционной функции. Относительная амплитуда этого пика свидетельствует о степени когерентности двухмасштабных импульсов. Видно, что при изменении степени когерентности импульсов ширина спектра излучения стоксовой волны может изменяться более, чем в два раза.

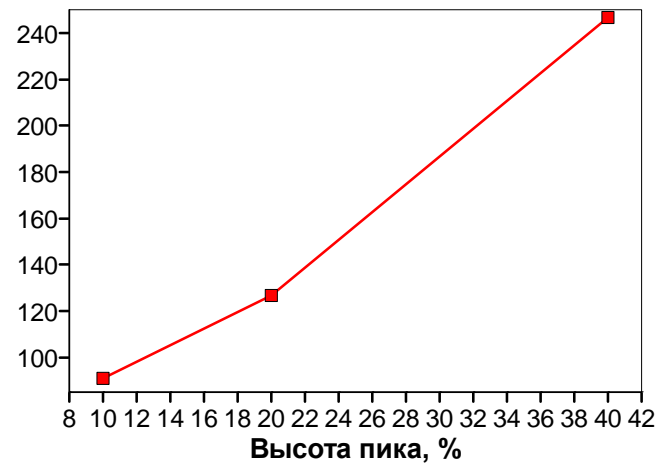

Рис. 3. Зависимость ширины оптического спектра на выходе катушки Р2О5 волокна, измеренная по основанию спектра, от высоты пика АКФ импульсов.

Таким образом, впервые выявлено, что степень когерентности двухмасштабных импульсов, генерируемых в волоконных лазерах с синхронизацией мо излучения, существенным образом влияет на ключевые свойства их ВКР-преобразования.

Данная работа поддержана грантами РФФИ 16-02-00104 и 16-32-60160.

\section{Литература}

[1] S.V. Smirnov, et al, Opt. Express 20(24), 27447-27453 (2012)

[2] S.M. Kobtsev, et al, Opt. Express 17(23), 20707-20713 (2009)

[3] S. Kobtsev, et al, Opt. Express 16(26), 21936-21941 (2008)

[4] A.Ivanenko, et al, Opt. Express, 24(6), 6650-6655 (2016)

[5] Y.S. Fedotov, et al, Opt. Express 22(25), 31379-31386 (2014)

[6] S. Smirnov, et al, Opt. Express 22(1), 1058-1064 (2014)

[7] S. Kobtsev, et al, Opt. Express 22(17), 20770-20775 (2014). 